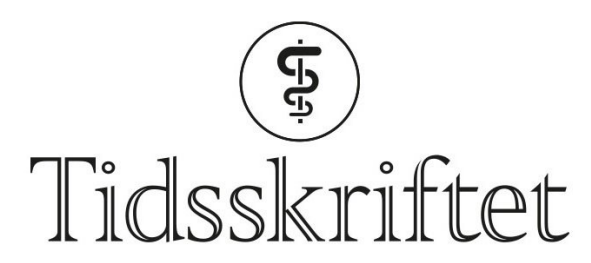

DEN NORSKE LEGEFORENING

\title{
Minneord: Ruth Bostad
}

MINNEORD

OLA H. SKJELDAL

MAGNHILD RASMUSSEN

JON BARLINN

KJERSTI RAMSTAD

PETTER STRØMME

INGER SANDVIG

TORE SELBERG

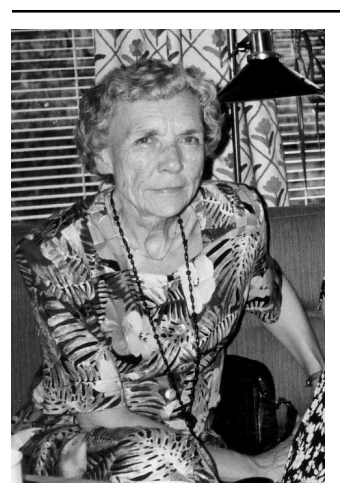

Tidligere overlege Ruth Bostad fra Oslo døde 20. mai 2017. Hun ble 84 år gammel.

Ruth tok sin medisinske embetseksamen i 1957 og ble spesialist i barnesykdommer i 1966. I hele sitt yrkesaktive liv arbeidet hun med nevrologiske sykdommer hos barn og med habilitering, og ble en av nestorene innenfor norsk barnenevrologi. Som overlege ved Barneklinikken på Rikshospitalet og Sentralinstituttet for habilitering (Berg gård) opparbeidet hun seg en betydelig kunnskap og erfaring og var faglig høyt ansett blant kolleger, også utenfor medisinen. Vi som arbeidet sammen med henne, opplevde henne som engasjert, kunnskapsrik og alltid imøtekommende og villig til å lære fra seg. Hun var en utmerket lærer, noe som flere av oss hadde glede av. I tillegg var hun en eminent kliniker med særdeles god observasjonsevne, og et godt medmenneske med stor empati. Ruths interesse og omsorg for pasientene betydde svært mye for barna og deres foreldre. De opplevde henne som omsorgsfull, støttende og tillitsskapende. Det er viktige egenskaper 
hos en barnelege.

Ruth hadde brede interesser, men barn med cerebral parese, barn med ryggmargsbrokk og barn med progredierende nevrologiske sykdommer sto henne særlig nær. Hun var spesielt interessert i Retts syndrom og publiserte sammen med overlegekollega Ragnhild Kiil den første beskrivelsen av dette syndromet på norsk.

Ruth har betydd mye for norsk barnenevrologi, oppbygging av habiliteringsfeltet og arbeidet for jenter og kvinner med Retts syndrom i Norge. Vi føler stor takknemlighet for at vi fikk lære henne å kjenne og lære av henne. Våre tanker går til hennes nærmeste.

Publisert: 21. august 2017. Tidsskr Nor Legeforen. DOI: 10.4045/tidsskr.17.0519

(C) Tidsskrift for Den norske legeforening 2020. Lastet ned fra tidsskriftet.no 